\title{
Pilot study of population density and biodiversity index of Mantodea fauna in El-
} Fayoum governorate- Egypt

\section{Rabab F. Sawaby - Hayam El-Hamouly and Mohammad G. El-Din Nasser}

\section{ABSTRACT}

The present work was carried out to make a pilot study of mantis population using mark release recapture technique in El-Fayoum governorate through the year of 2008 to estimate the population density and the biodiversity of some mantis fauna. This study form a nucleus of more extensive studies on mantis ecology which is still not clear and shed the light on the nature of mantis population and some problems facing this beautiful insect in Egypt.

Key word: Marking release technique, population density, biodiversity, Mantodea, El-Fayoum, Egypt.

\section{INTRODUCTION}

Mantodea is a small insect order represented by 2452 species on 446 genera and 14 families around the world (Otte\& Spearman, 2005). Mantodea of Egypt form one of unique and sophisticated mantis fauna on the planet, with 59 species on 21 genera and 4 families (Nasser 2010). All mantis are predators feeding mainly on other insects and arthropods (Preston, 1990; Ehrman, 1992). Mantis are diurnal insects live mainly on tropical and sub-tropical regions with only few species occur on cold area (Ehrman, 2001a). They live solitary on trees, shrubs and grasses, to make their camouflage mission to get their prays and avoiding enemies. Only the species of two genera Eremiaphila and Heteronutarsus of family Eremiaphilidae found on the sand of the desert and get prays by fast attack (Hessler, et al, 2008).

From economic point of view, the praying mantis are welcomed in all gardens and fields with hope that they will consume many plant pests in these fields. As any other biological control agent, the population density of praying mantis playing the key role on its impact on pest populations so with the increase of number of mantis on fields and gardens we can achieved acceptable level of control, tacking on consideration the bad effect of this increase on other beneficial insects including other mantis (Carroll \& Salt, 2004; Jervis, 2005).

\section{MATERIAL AND METHODS}

The population density study is took place through the year of 2008 in ElFayoum governorate. Four different localities were chosen (Kom Osheam, Senoris, Ebshuay and El-Lahoun) to study mantis fauna in the governorate.

The individuals were collected using sweeping nets and hand picking by visual inspection of the surroundings. Each individual was marked on pronotum using water proof colors and then released in the same site of recapture.

Each locality was investigated twice during the study year. Three successive visits were applied for each investigation; the first two visits for marking and 
identifying of the species present and the third visit for recapturing. The maximum period between marking and recapturing took about 14 days.

\begin{tabular}{|c|c|c|}
\hline Kum Osheam & Semi desert habitat & $50 \mathrm{~m}$ from the Cairo/ El-Fayoum highway with an area of $500 \mathrm{~m}^{2}$ \\
\hline Senoris & Agricultural farms & $80 \mathrm{~m}$ from the Cairo/ Fayoum highway with an area of $500 \mathrm{~m}^{2}$ \\
\hline Ebshuay & March agricultural farm & $40 \mathrm{~m}$ from Qarun highway and has an area of $500 \mathrm{~m}^{2}$ \\
\hline El-Lahoun & Agricultural farms & $20 \mathrm{~m}$ from the Fayoum/ BeniSuaf highway and has an area of $500 \mathrm{~m}^{2}$ \\
\hline
\end{tabular}

Data collected were used to calculate the total mantis population density for all species also to calculate species richness, biodiversity index and Simpson index of diversity through the year for the four localities.

The marking release recapture data were analyzed using derivation of the Lincoln-Petersen and Fisher \& Ford equations:

$\mathrm{N}=$ Estimate of total population size

$$
N=\frac{(M+1)(C+1)}{R+1}-1,
$$

$\mathrm{M}=$ Total number of mantis captured and marked on the first and second visits.

$\mathrm{C}=$ Total number of mantis captured on the third visit

$\mathrm{R}=$ Number of animals captured on the first and second visits that were then recaptured on the third visit.

The data collected were also used to calculate species richness, biodiversity index and Simpson index of diversity using the following equations:

$\mathrm{R}=$ species richness.

$$
\mathrm{R}=\mathrm{s} / \sqrt{ } \mathrm{N}
$$

$\mathrm{S}=$ number of species recorded.

$\mathrm{N}=$ total number of individuals collected of all species.

$$
\mathrm{D}=(\mathrm{n} / \mathrm{N})^{2}
$$

$\mathrm{D}=$ Biodiversity index.

$\mathrm{n}=$ the total number of specimens of a particular species.

$\mathrm{N}=$ the total number of organisms of all species.

$$
\mathrm{S}=1-\mathrm{D}
$$

$\mathrm{S}=$ Simpson index of diversity.

$\mathrm{D}=$ Biodiversity index.

The individuals were collected using sweeping nets and hand picking by visual inspection of the surroundings. Each individual was marked on pronotum using water proof colors and then released in the same site of recapture. The biodiversity index and Simpson index of diversity are inversely proportional with each other, but the two ranges from 0 to 1 . In the biodiversity index, the closer result of calculation from scratch the high the diversity of the region and the closer to one the low diversity of the region it was. Simpson index of diversity is refers to biodiversity index and more compatable with our thinking as one is higher than zero (Foottit \& Adler 2009).

\section{RESULTS}

During this study 135 individuals of mantis were recorded, 93 of them were marked, 30 of them were recaptured; about $50 \%$ of this number was recaptured from the same position of marking. The most important observation recorded during this work is the absence of co-occurrence of two mantis species on the same plant and variation of position of each species in each ecosystem studied. 


\section{Analyzing of Mantodea population in the four chosen localities: Kum Osheam}

The first investigation was made during March; four species of mantis were collected (Sphodromantis viridis Forskål - Miomantis paykullii Stål - Empusa sp.Oxyothespis dumonti Chopard) all of them in nymph stage, on the first two visits11 individuals were marked for three species (Empusa sp.-Miomantis paykullii Stål,Oxyothespis dumonti Chopard) as only one individual of Sphodromantis viridis Forskål was recorded from the area during these visits. Recapturing took place seven days after marking process ended and 7 individuals were recaptured 4 of them were marked. The estimation of mantis population in the area was 18.2 individuals.

The second investigation occurred during June and the first week of July in the same way; 3 species were recorded (Oxyothespis dumonti Chopard-Sphodromantis viridis Forskål - Eremiaphila sp.) on the first two visits; 7 individuals were marked of adult Oxyothespis dumonti Chopard and Sphodromantis viridis Forskål as only one individual of Eremiaphila sp. were captured. During the third visits 8 individuals were recaptured 4 of them were marked. The estimation of mantis population in the area became 13.4 individuals.

The data of the two investigations were used to calculate species richness and biodiversity index and Simpson index of diversity (Tables. 1, 2, 9 \& 10 and Figs.1 \& 2).

Table 1: The data of marking release recapturing method and the corresponding estimation of population density for the first and second investigation on Kum Osheam area.

\begin{tabular}{|c|c|c|c|c|}
\hline & $\begin{array}{c}\text { Marked on the } \\
\text { first visits }\end{array}$ & $\begin{array}{c}\text { Recaptured } \\
\text { individuals }\end{array}$ & $\begin{array}{c}\text { Marked } \\
\text { individuals of } \\
\text { recaptured }\end{array}$ & $\begin{array}{c}\text { Estimation of } \\
\text { population } \\
\text { density }\end{array}$ \\
\hline First investigation & 11 & 7 & 4 & 18.2 \\
\hline $\begin{array}{c}\text { Second } \\
\text { investigation }\end{array}$ & 7 & 8 & 4 & 13.4 \\
\hline
\end{tabular}

Table 2: The number of mantis individuals recorded for each species through the year and corresponding species richness and biodiversity index for Kum Osheam area.

\begin{tabular}{|c|c|}
\hline Species recorded & Number of individuals \\
\hline Eremiaphila $s p$. & 1 \\
\hline Empusa sp. & 4 \\
\hline MiomantispaykulliiStal & 3 \\
\hline OxyothespisdumontiChopard & 10 \\
\hline SphodromantisviridisForskal & 7 \\
\hline Species richness & 0.2816 \\
\hline Biodiversity index & \\
\hline
\end{tabular}

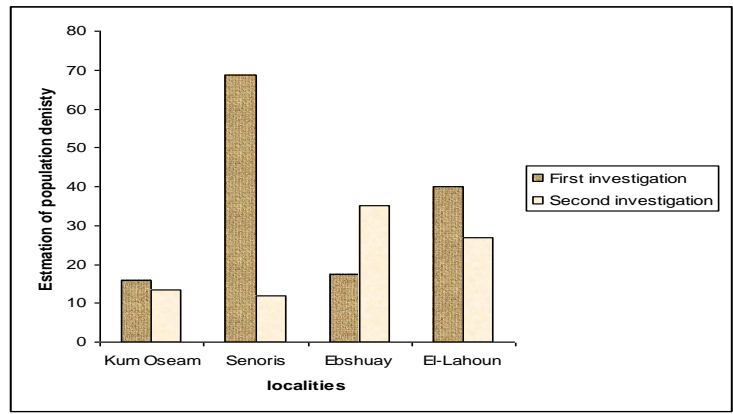

Fig. 1: The relation between the estimation of mantis population density in first and second investigations in the four chosen localities. 


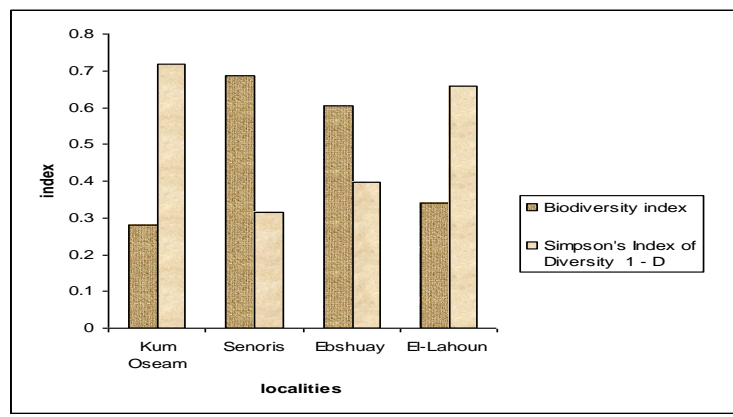

Fig. (2) The relation between the biodiversity index and Simpson index of diversity in the four chosen localities.

\section{Senoris:}

The first investigation occurred during April; 3 species were recorded from the area Sphodromantis viridis Forskål - Miomantis paykullii Stål, and Oxyothespis dumonti Chopard, all of them in the nymphal stage, on the first two visits, 18 individuals of Sphodromantis viridis Forskål and Miomantis paykullii Stål, were marked as only one individual of Oxyothespis dumonti Chopard, was captured on the first visit. The recapture took place after seven days after marking process ended and 10 individuals were recaptured 2 of them were marked. The estimation of mantis population in the area was 68.67 individuals.

The second investigation was made during July in the same way; only 1 species were recorded SphodromantisviridisForskål, 8 individuals were marked in the first two visits and then 9 individuals were recaptured 6 of them were marked. The estimation of mantis population in the area became 11.86 individuals.

The data of the two investigations were used to calculate species richness, biodiversity index and Simpson index of diversity (Tables 3, 4, $9 \& 10$ and Figs. $1 \& 2$ ).

Table 3: The data of marking release recapturing method and the corresponding estimation of population density for first and second investigations on Senoris area.

\begin{tabular}{|c|c|c|c|c|}
\hline & $\begin{array}{c}\text { Marked on the first } \\
\text { visits }\end{array}$ & $\begin{array}{c}\text { Recaptured } \\
\text { individuals }\end{array}$ & $\begin{array}{c}\text { Marked individuals } \\
\text { of recaptured }\end{array}$ & $\begin{array}{c}\text { Estimation of population } \\
\text { density }\end{array}$ \\
\hline $\begin{array}{c}\text { First } \\
\text { investigation }\end{array}$ & 18 & 10 & 2 & 68.67 \\
\hline $\begin{array}{c}\text { Second } \\
\text { investigation }\end{array}$ & 8 & 9 & 6 & 11.86 \\
\hline
\end{tabular}

Table 4: The number of mantis individuals recorded for each species through the year and corresponding species richness and biodiversity index for Senoris area.

\begin{tabular}{|c|c|}
\hline Species recorded & Number of individuals \\
\hline MiomantispaykulliiStal & 5 \\
\hline OxyothespisdumontiChopard & 26 \\
\hline SphodromantisviridisForskal & 0.53 \\
\hline Species richness & 0.6855 \\
\hline Biodiversity index & \\
\hline
\end{tabular}

\section{Ebshuay}

The first investigation was made during the last week of April and the first two weeks of May; only one species Miomantis paykullii Stål, were recorded on the first two visits, 6 individuals of this species were marked and then 9 individuals of this species were recaptured 3 of them were marked.The estimation of mantis population in the area was 16.5 individuals.

The second investigation was made during August in the same way; two species were recorded (Miomantis paykullii Stål, and Sphodromantis viridis Forskål) and 14 individuals were marked in the first two visits and then 11 individuals were recaptured 
4 of them were marked. The estimation of mantis population in the area became 35 individuals.

The data of the two investigations were used to calculate species richness and biodiversity index and Simpson index of diversity (Tables: 5, 6, $9 \& 10$ and Figs. $1 \& 2)$.

\section{El-Lahoun}

The first investigation was made during May, 4 species Empusa pennata Thunberg, Miomantis paykullii Stål, Sphodromantis viridis Forskål and Iris oratoria Linne., were recorded on the first two visits, 18 adult individuals were marked and then 12 individuals were recaptured 5 of them were marked. The estimation of mantis population in the area was 40.1 individuals.

The second investigation was made during September in the same way; two species were recorded Miomantis paykullii Stål, and Sphodromantis viridis Forskål and 11 individuals were marked in the first two visits and then 6 individuals were recaptured 2 of them were marked. The estimation of mantis population in the area became 27 individuals.

Table 5: The data of marking release recapturing method and the corresponding estimation of population density for the first and second investigationsin Ebshuay area.

\begin{tabular}{|c|c|c|c|c|}
\hline & $\begin{array}{c}\text { Marked on the } \\
\text { first visits }\end{array}$ & $\begin{array}{c}\text { Recaptured } \\
\text { individuals }\end{array}$ & $\begin{array}{c}\text { Marked } \\
\text { individuals of } \\
\text { recaptured }\end{array}$ & $\begin{array}{c}\text { Estimation of } \\
\text { population } \\
\text { density }\end{array}$ \\
\hline $\begin{array}{c}\text { First } \\
\text { investigation }\end{array}$ & 6 & 9 & 3 & 16.5 \\
\hline $\begin{array}{c}\text { Second } \\
\text { investigation }\end{array}$ & 14 & 11 & 4 & 35 \\
\hline
\end{tabular}

Table 6: The number of mantis individuals recorded for each species through the year and corresponding species richness and biodiversity index for Ebshuay area.

\begin{tabular}{|c|c|}
\hline Species recorded & Number of individuals \\
\hline MiomantispaykulliiStal & 24 \\
\hline SphodromantisviridisForskal & 9 \\
\hline Species richness & 0.3481 \\
\hline Biodiversity index & 0.6033 \\
\hline
\end{tabular}

The data of the two investigations were used to calculate species richness, biodiversity index and Simpson index of diversity (Tables: 7, 8, $9 \& 10$ and Figs.1 \& 2).

Table 7: The data of marking release recapturing method and the corresponding estimation of population density for the first and second investigations in El-Lahoun area.

\begin{tabular}{|c|c|c|c|c|}
\hline & $\begin{array}{c}\text { Marked on the } \\
\text { first visits }\end{array}$ & $\begin{array}{c}\text { Recaptured } \\
\text { individuals }\end{array}$ & $\begin{array}{c}\text { Marked } \\
\text { individuals of } \\
\text { recaptured }\end{array}$ & $\begin{array}{c}\text { Estimation of } \\
\text { population } \\
\text { density }\end{array}$ \\
\hline $\begin{array}{c}\text { First } \\
\text { investigation }\end{array}$ & 18 & 12 & 5 & 40.1 \\
\hline $\begin{array}{c}\text { Second } \\
\text { investigation }\end{array}$ & 11 & 6 & 2 & 27 \\
\hline
\end{tabular}


Table 8: The number of mantis individuals recorded for each species through the year and corresponding species richness and biodiversity index for El-Lahoun area.

\begin{tabular}{|c|c|}
\hline Species recorded & Number of individuals \\
\hline Empusapennata Thunberg. & 3 \\
\hline Iris oratoriaLinne. & 5 \\
\hline MiomantispaykulliiStal & 16 \\
\hline SphodromantisviridisForskal & 16 \\
\hline Species richness & 0.6324 \\
\hline Biodiversity index & 0.3412 \\
\hline
\end{tabular}

Table 9: The estimation of Mantodea population density for the four chosen localities on first and second investigations.

\begin{tabular}{|c|c|c|}
\hline & First investigation & Second investigation \\
\hline KumOseam & 18.2 & 13.4 \\
\hline Senoris & 68.67 & 11.86 \\
\hline Ebshuay & 16.5 & 35 \\
\hline El-Lahoun & 40.1 & 27 \\
\hline
\end{tabular}

Table 10: The biodiversity index and Simpson index of diversity for the four chosen localities.

\begin{tabular}{|c|c|c|}
\hline & Biodiversity index & Simpson's Index of Diversity 1-D \\
\hline KumOsheam & 0.2816 & 0.7184 \\
\hline Senoris & 0.6855 & 0.3145 \\
\hline Ebshuay & 0.6033 & 0.3967 \\
\hline El-Lahoun & 0.3412 & 0.6588 \\
\hline
\end{tabular}

\section{DICUSSION}

The mantis like any other creature affected greatly by biotic and abiotic component that found on their habitat background. Before the study of population density and biodiversity index of Mantodea fauna in El-Fayoum governorate began, we collected almost every data needed to understand the mantis habitat. So, the result of our pilot study can be easily discussed in the shadow of this data.

The population density of mantis in $75 \%$ of localities (Kum Osheam, Senoris and El-Lahoun) reduced as the season progresses and this agrees with the comment of Weinzeral \& Hennin (1998) on mantis population as they stated that only one individual of mantis from each ootheca can live to the end of the season. Cannibalism, either sexual or nymph-nymph cannibalism, which is common in the order is said to be one of the most important reasons for this reduction, but many other factors can play the role in that: the observation of large number of insect-eating birds like Egyptian plovers which search vegetation for grasshoppers and other large insects, observation of large number of lizards especially on El-Lahoun and the effect of frequently used insecticides in the governorate especially on Senoris. This is compatible with the work of Hurd et al. (1978) on Chinese mantis population.

The using of marking recapturing technique in studying the population density of any organism gives an idea of the movement and distribution of this organism through habitat (Corbet 1952 \& Sheppard et. al. 1969). About 50\% of recaptured individuals were collected from the same position of marking and this gives initial idea about a low rate of movement of this creature. Combining this with the observation indicating the absence of occurrence of two different individuals of mantis on the same herb or shrubs, we can conclude that mantis populations are distributed through habitat by separating territories. This agrees with the comment of Bischoff et al. in their book about mantis life (2001) which stated that "mantis are solitary insects living in separated islands through their habitat and can only observed in couples during mating seasons in late summer". 
During this work different mantis species were recorded in co-occurrence in all localities under investigation. Each species has its niche and observations indicated that Eremiaphila sp. is found on naked ground especially on sand and rocks, Oxyothespis dumonti Chopard, prefer spiny herbs and sandy soils; Miomantis paykullii Stål, prefer green grasses and small plants; Empusa pennata Thunberg, Iris oratoria Linne, and Sphodromantis viridis Forskål perefer shrubs but in different positions. This is also agrees with previous studies of mantis co-occurrence and competitions (Rathet \& Hurd 1983 \& Kral 1999).

The result of mantis biodiversity index and Simpson index of diversity indicated that the biodiversity of mantis fauna in Kum Osheam is higher than in any other localities although this city is much more polluted than any other one. This may be due to the absence of large area of man-made Agro-ecosystem which including use of insecticides and this appear in all area studied except Kum Osheam. In general the biodiversity index and Simpson index gave an idea of the vitality and stability of any ecosystem (Foottit \& Adler2009) and this means that Kum Osheam is more stable than the three other localities but this until now, as many and many industrial project will being started every year in the area and this will greatly affect the surrounding environment during the next few years.

The study indicated that the use of mantis as a biological control agent is facing many problems and need more intensive investigations.

\section{REFRENCES}

Berryman, A. A. and Kindlmann, P. (2008). Population Systems "A General Introduction" -Springer Science + Business Media B.V.; 106, 177, 179 and 189.

Carroll, S.B. \&Salt, S.D. (2004). Ecology for Gardeners -Published by Timber Press, P: 204, USA.

Conradt, L. Roper, T. J. and Thomas C. D. (2001). Dispersal Behaviour of Individuals in Metapopulations of Two British Butterflies. Oikos, 95(3): 416-424.

Corbet, P. S. (1952). An Adult Population Study of Pyrrhosomanymphula (Sulzer): (Odonata: Coenagrionidae). Journal of Animal Ecology, 21(2):206-222.

Córdoba-Aguilar, A. (2008). Dragonflies and Damselflies "Model organisms for ecological and evolutionary research" .Oxford University Press; P:7-10.

Edmunds M. (1986). The Phenology andDiveristy of Praying Mantids in Ghana Journal of Tropical Ecology, 2 (1): 39-50.

Ehrmann, R. (1992). WirbeltierealsNahrung von Gottesanbeterinnen (Mantodea). Entomol. Zeitschr., 102 (9): 153-162.

Ehrmann, R. (1996). Die Mantodea-Fauna von Ägypten. - Entomol. Zeitschr., 106(10): 410-424, 2 fig.

Ehrmann, R. (2001). Gottesanbeterinnen (Mantodea)-EineUbersicht: Teil 1: Stammesge-schichte, Systematik, Korperbau, Fortpflanzung. Reptilia, 6 (28): 26-32.

El Khatib, M. and El Khatib, M. (2006). Fayoum Ecotourism 2005-2015 - EDG; P: 22-26.

Foottit, R. G. and Adler, P. H. (2009). Insect Biodiversity "Science and Society" Blackwell Publishing Ltd.; USA.

Hesseler, C. and Bischoff, I. (2008). Praxis Ratgeber: Mantiden, Faszinierende Lauerjager- Edition Chimaira, Frankfurt. 
Howard, R.W.and Blomquist, G. (2005). Ecological, Behavioral, and Biochemical Aspects of Insect Hydrocarbons-Annual Review of Entomolo., 50 (1): 371-393.

Hurd, L. E., Eisenberg, R. M. and Washburn, J. O. (1978). Effects of Experimentally Manipulated Density on Field Populations of the Chinese Mantis (Tenoderaardifoliasinensis Saussure). American Midland Naturalist, 99 (1): 58-64.

Jervis, M. (2005). Insects as Natural Enemies: A Practical Perspective- Published by Springer, P: 249.

Kral, K. (1999). The coexistence of Mantis religiosa and Empusafasciata in a shared habitat. MSG, N1.2: 8-10.

Otte, D. \& Spearman, L. (2005). Mantida- species file. Catalog of the Mantids of the World. Insect Diversity Association Publication, 1:1- 489.

Preston-Mafham, K.G. (1990). Grasshoppers and Mantids of the world. Blandford Book, (119-120).

Rathet, I. H. and Hurd, L. E. (1983). Ecological Relationships of Three Co-occurring Mantids, Tenoderasinensis (Saussure), T. angustipennis (Saussure), and Mantis religiosa (Linnaeus).American Midland Naturalist, 110 ( 2): 240-248.

Sheppard, P.M.; Macdonald, W. W. Tonn, R. J. and Grab B. (1969). The Dynamics of an Adult Population of Aedesaegypti in Relation to Dengue HemorrhagicFever in Bangkok.Journal of Animal Ecology, 38(3): 661-702.

Weinzeral, R. and Henn, T. (1998) Alternative in Insect Management, Biological and Biorational Approaches. North Central Regional Extension Publications,P: 62.

White, D. S. and Henschen, M. T. (1978). A Mark-Recapture Method for Adult Caddisflies (Insecta: Trichoptera).The Southwestern Naturalist, 23(3): 533-536.

\section{ARABIC SUMMARY}

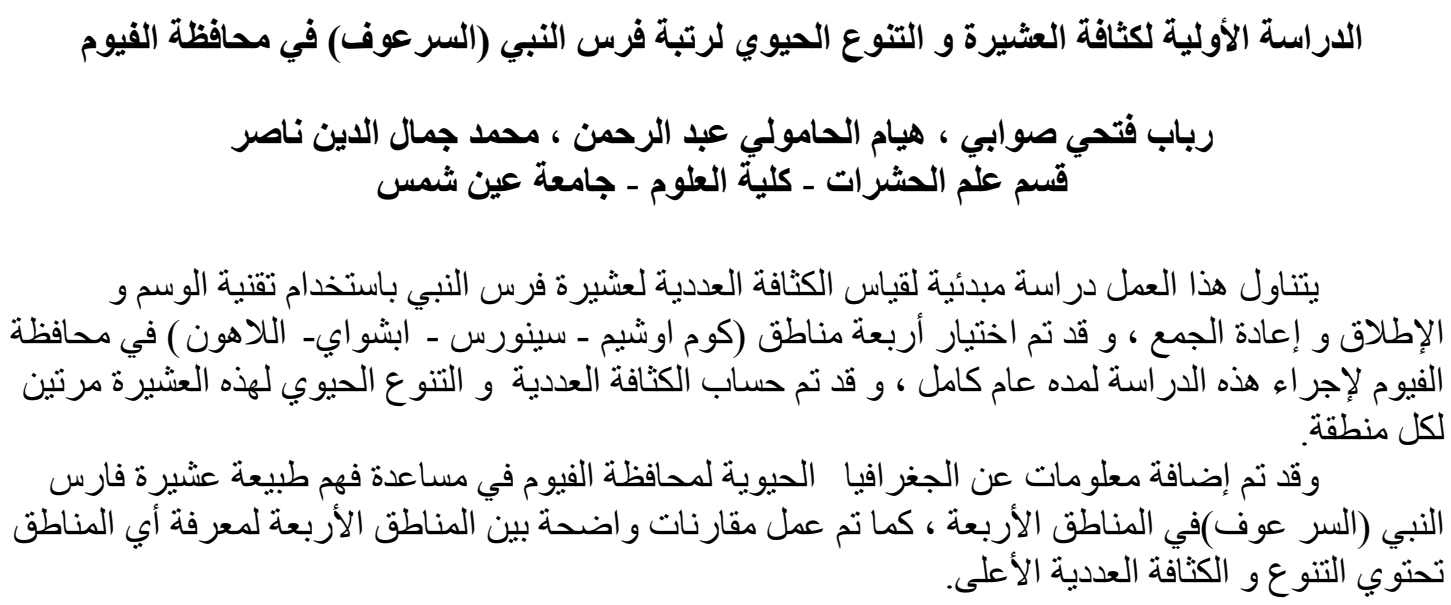

